University for Business and Technology in Kosovo

UBT Knowledge Center

UBT International Conference

2014 UBT International Conference

Nov 8th, 11:30 AM - 11:45 AM

\title{
Pushover Analysis Method for Performance Based Seismic Design
}

\author{
Misin Misini \\ University of Prishtina, misin.misini@uni-pr.edu \\ Zijadin Guri \\ University Skopje, guri.zijadin@gmail.com \\ Ylli Pocesta \\ University Skopje, yllipocesta@gmail.com \\ Armend Mujaj \\ Polytechnic University of Tirana, armend20mujaj@gmail.com
}

Follow this and additional works at: https://knowledgecenter.ubt-uni.net/conference

Part of the Architecture Commons

\section{Recommended Citation}

Misini, Misin; Guri, Zijadin; Pocesta, Ylli; and Mujaj, Armend, "Pushover Analysis Method for Performance Based Seismic Design" (2014). UBT International Conference. 15.

https://knowledgecenter.ubt-uni.net/conference/2014/all-events/15

This Event is brought to you for free and open access by the Publication and Journals at UBT Knowledge Center. It has been accepted for inclusion in UBT International Conference by an authorized administrator of UBT Knowledge Center. For more information, please contact knowledge.center@ubt-uni.net. 


\title{
Pushover Analysis Method for Performance Based Seismic Design
}

\author{
Misin Misini ${ }^{1}$, Zijadin Guri ${ }^{2}$, Ylli Pocesta ${ }^{3}$, Armend Mujaj ${ }^{4}$ \\ ${ }^{1}$ Univeristy of Prishtina, Faculty of Civil Engineering and Architecture, \\ ${ }^{23}$ University, Faculty of Civil Engineering in Skopje, \\ ${ }^{4}$ Politechnical University,Faculty of Civil Engineering in Tirana, \\ misin.misini@uni-pr.edu ${ }^{1}$, armend20mujaj@gmail.com², guri.zijadin@gmail.com³ \\ yllipocesta@gmail.com ${ }^{4}$
}

\begin{abstract}
In this paper is describes a non-linear static (pushover) analysis method for reinforced concrete structures that predicts real nonlinear (both material and geometrical) behavior including all stages of loading, starting from the initial application of loads up to and beyond the collapse of building. In other words from appearance of first plastic hinge until last hinge which represent collapse of building. Some important aspects which are implemented in EC8, FEMA-273/356 and ATC-40 documents regarding to pushover analysis and performance evaluation of buildings are discussed. Modeling of structural elements is made by linear elements approach. Nonlinear behavior of structural elements is made by plastic hinges when inelastic behavior is concentrated at plastic hinge locations in both ends of elements. For monitoring structural degradation of beams, bilinear Moment-Rotation relationship is considered. For monitoring structural degradation of columns, PMM interaction surface is considered. Nonlinear geometrical effects are taken into account by incorporating both local $(\mathrm{P}-\delta)$ and global (P- $\Delta)$ in analysis. An eight story reinforced concrete building is analyzed. Distribution of lateral loads is accepted by first mode of free vibration. Results are given in terms of Global Capacity Curve, sequences of plastic hinge formation, plastic hinge distribution in structure, performance levels in terms of local behavior of structural elements and global behavior of structure.
\end{abstract}

Keywords: Pushover Analysis, Nonlinear Behavior, Plastic Hinge, Collapse

\section{Introduction}

In conventional elastic calculations practice, it has been created impression that the energy absorbing structures, the ability of ductile behavior in non-elastic stage, is able to withstand loads caused by earthquakes. But seismic events such as earthquakes in Northridge, California (1994), Kobe, Japan (1994), etc.., clarified the inefficiency of such existing methods. Thus, the engineering analysis of the consequences caused by earthquakes, structural damage control, respectively, initiated the idea of changing the existing design methodology. Such conclusions refer to Performance Based Design- BPD. To evaluate the performance of the structure, subjected to seismic action, the best way is non-linear time history analysis. This analysis can be accomplished and justified only in very special cases, and as such limits its application in daily practice or for solving normal engineering problems.

Application of design principles need to be defined based on performance analysis procedures, bypassing the difficulties of calculating excess. Non-linear static procedures among others, are among the most rational, because they are simple to use and practical for solving of many engineering structures.

Since the design is not focused on defining a single methodology of non-linear static procedures, the most suitable procedures that make use of analysis based on pushover, are summarized briefly and clearly in many codes: FEMA 356 (ASCE, 2000), ATC-40 (ATC, 1996), FEMA 440 (ATC, 2005) and the EC 8 (ENV 1998-1, 1994). 


\section{Performance Based Seismic Engineering - PBSE}

Design of building structures in seismic regions intended as a defense of their safe against possible earthquakes, seeking the correct engineering solution, but also economically acceptable. The experiences of many designs and constructions in seismic areas, but particularly the engineering analysis of the effects of real earthquakes remain major factors for the formulation, in principle, reasonable solutions, expressed in the basic requirements and the relevant anti-seismic design criteria. Any structural system is designed so that it has a capacity that exceeds seismic demand - previously known. In each concrete case, the ability of the designer lies in establishing the right relationship between reasonable seismic engineering requirements and structural capacity. But this should be a primary goal to determine the target performance of structure, choosing between options associated with a specific level of seismic hazard. The term concept of using "performance" relates to the provision of predetermined expected objectives of structural behavior during seismic operations data. Depending on the intensity of a significant earthquake, resulting seismic responses differentiated between themselves. Earthquake can be moderate, not strong, then the probability of major decline, but more important is the assessment of a possible strong earthquake or very strong, with low probability. In accordance with the intensity of earthquakes determined the so-called basic requirements and corresponding design criteria and the relevant boundary conditions. In European Normative (EC8) as recommended value for the acceleration of seismic design action or, in short, given the earthquake design its period of repetition, $\mathrm{PR}=475$ years. This value corresponds to a probability of only $10 \%$ to exceedance the design earthquake intensity within a 50-year period. As a measure of the intensity of the seismic action, in EC8, is used the so-called design acceleration Ag in rocky or hard ground. In technical literature is discussed the possibility of a very large seismic action, the extraordinary, the "maximum possible earthquake." In cases when this action is treated, damages may be accepted, provided that they again collapse of the building be avoided and people's life will be guaranteed. Referring to the experiences that have been implemented in anti-seismic design practice, there are given maximum acceleration the relationship between the land and the annual probability of recurrence or PR period, for three seismic levels (high, moderate and low).

Performance Goal has two essential part: the damage state and a corresponding level of seismic hazard. So seismic performance described by reference to maximum allowed damages state (this is the level of performance), caused by a seismic risk level identified or expected ground motion during the earthquake. Among the most significant levels of structural performance are: immediate use of the building (Immediate Occupancy-IO); Safety of Life (Life Safety-LS) and collapse prevention (Collapse Prevention - CP). Corresponding levels of damages are presented in Fig. 1

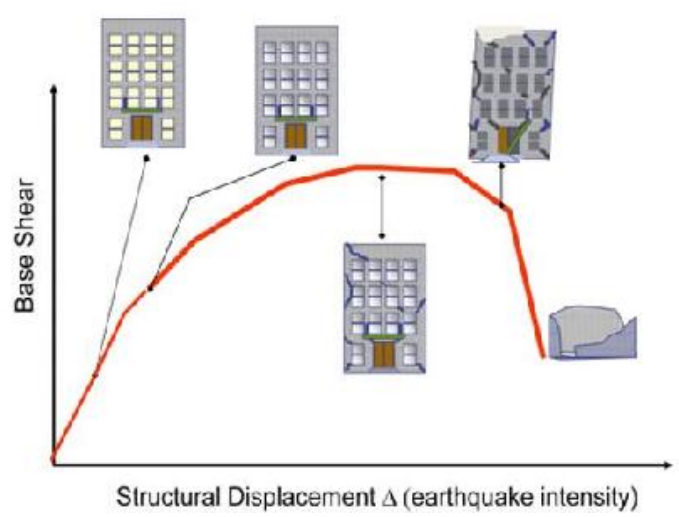




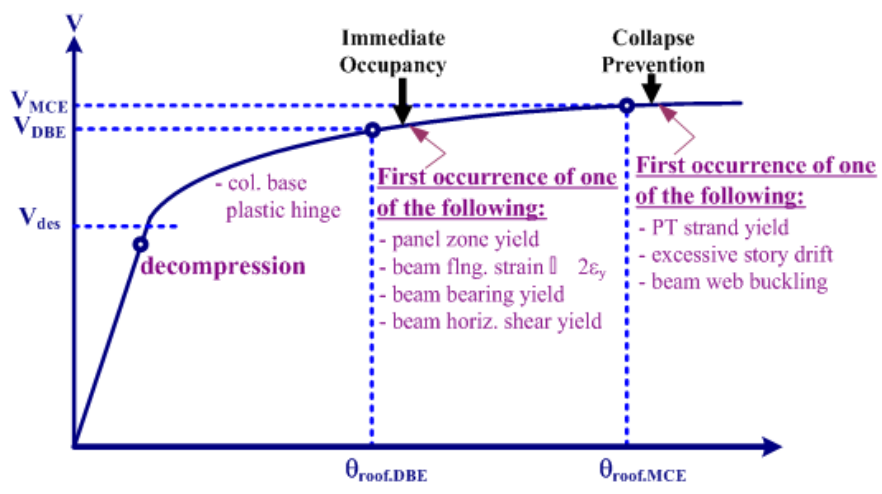

Fig. 2. Performance Levels and Corresponding Damage Levels

Expected performance can be assessed by comparing the seismic capacity requirements corresponding to the required level of performance. Thus, the global performance of the structure can be visualized graphically, comparing the capacity with the demand. On this basis, the analysis can be made of the expected damage to the structure. A detailed description of the damage done to the levels of performance, are given below:

Table 2. Performance Levels expressed in terms of damages in structural elements.

\section{Operational Level}

- This is the performance level related to functionality and any required repairs are minor.

\section{Immediate Occupancy level}

- This corresponds to the most widely used criteria for essential facilities. The building's spaces and systems are expected to be reasonably usable

\section{Life Safety Level}

- This level is intended to achieve a damage state that presents an extremely low probability of threat to life safety, either from structural damage or from falling or tipping of nonstructural building component

\section{Collapse Prevention Level}

- This damage state addresses only the main building frame or vertical load carrying system and requires only stability under vertical loads.

In general, the process of performance-based design is illustrated in figure Fig. 2. Initially performance targets are defined and then the conceptual design is performed, in order to achieve those objectives, while further are verify if performance targets are met, if not, accounts repeated until performance targets are achieved. The effects of geometric nonlinearity caused by vertical loads acting on the deformed configuration of the structure, which increases the internal effects of the elements of the structure. These geometric nonlinear effects differ between P- $\Delta$ effect associated with deformations along the element measured as the relative value of the element cord and P- $\Delta$ effect measured between the edges of the element and that are related to the relative displacement of stories. Structures subject to earthquake P- $\Delta$ effect is more important than the P- $\Delta$ and nonlinear analysis is not necessary to incorporate the P- $\Delta$ effect. Large horizontal displacements $\Delta$ increase internal forces of elements and cause a decrease in the effective horizontal stiffness. With increasing internal forces, a small part of the 
structure capacity remains available to accept horizontal loads, leading to a reduction in the resistance of the structure.

Figure Fig. 3. Is a curve showing the idealized force-displacement for a console structure with P- $\Delta$ effect and without. If the vertical load is high, the reduction of hardness (indicated by a negative angle IC) is important and contributes to the loss of horizontal resistance and instability. Therefore, effects related to the vertical loads and P- $\Delta$ effect should be incorporated in the analysis, whether static or dynamic. This means that the vertical loads analysis facility should be taken into consideration and must be incorporated P- $\Delta$ effect. (Wilson 2002; Powell 2010).

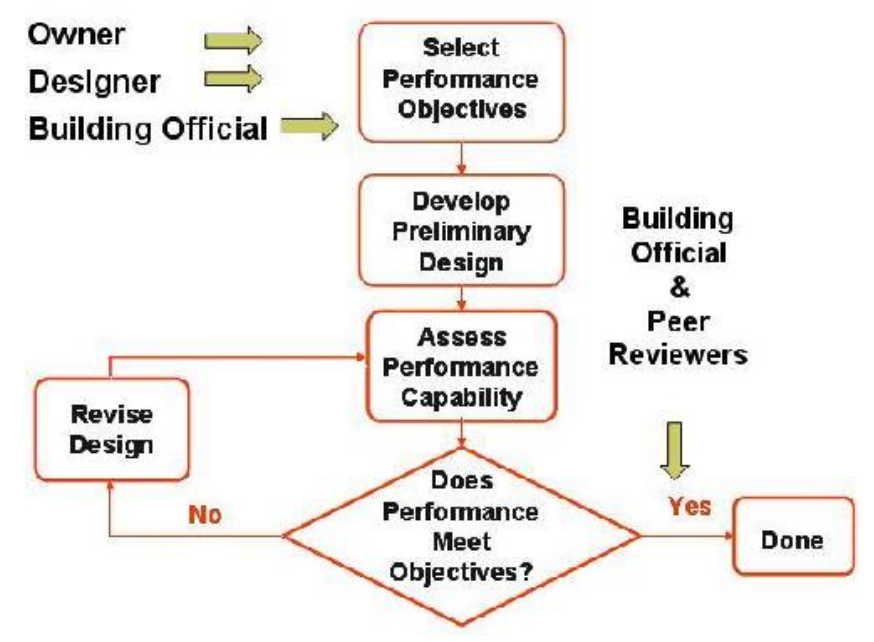

Fig. 2. Steps for performing Performance Based Seismic Design

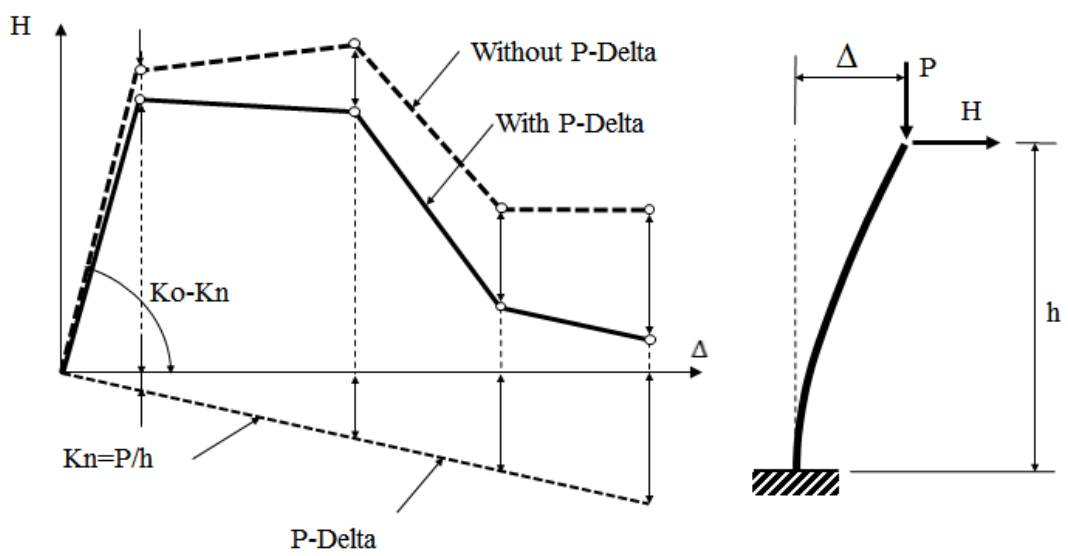

Fig. 3. Force-Displacement relation with and without P-Delta effect. 


\section{Nonlinear Static Analysis - Pushover Analysis}

Referring to studies that have started application of Performance based Seismic Design, they have assessed, in the first place, the analysis of gradual loading-Pushover Analysis. Historically, this analysis is used in the 70's of last century. In the middle of $90 \mathrm{~s}$, the potential of pushover analysis is verified and found its way to the seismic requirements Guide SEAOC 1995, FEMA 273/274, 1997, 1997 ATC-40 Nowadays Pushover Analysis enjoys more popularity and is involved in almost modern design codes, such as FEMA 356/357 2000, ATC-55, 2005; FEMA-440 2006; EC-8 (ENV 1998 to 1.1994). Pushover analysis is in no way definitive answer to the problems of design - analysis, but is an important step forward, which gives importance to those elastic response characteristics that would distinguish between good performance and the poor, in the case of strong earthquakes. The process consists in presenting an analytical model of structure with three dimensional elements, which takes into account all the important features of the response including linear and non-linear properties, previously defined shape of loading, which is approximately the relative inertia forces generated from earthquake, up to specific levels of target displacements. Pushover analysis accomplished by submitting a form distribution of lateral forces to structure that grow monotonically. This system conceptualized such forces to realistically represent as inertial forces that will withstand seismic structure during an earthquake. According to EC8 (CEN 2004a, 2005a) pushover analysis should be performed using distribution "modal" (Fig.-3a), which simulates the inertia forces according to the first vibration shape in the horizontal direction, or distribution "uniform" (fig. -3b), which corresponds to a uniform acceleration. More sophisticated versions of pushover analysis (Bracci et al. 1997, Elnashai 2001, Gupta and Kunnath 2000), using the adaptive distribution of lateral forces.

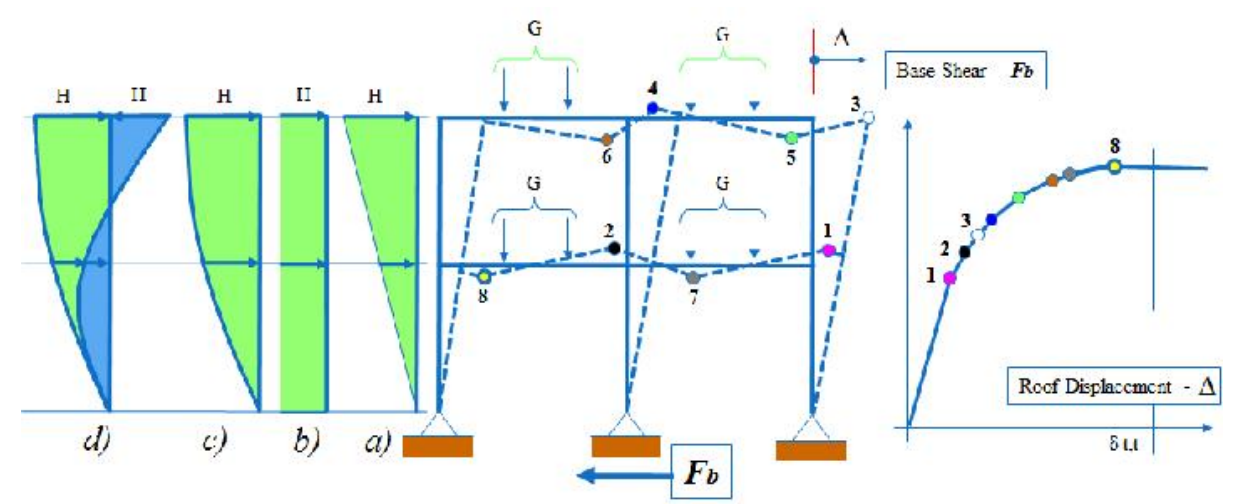

Fig. 4. Pushover Analysis Concept. Horizontal loads and Plastic Mechanism 
With the gradual increase of the lateral load, the different structural elements in fluency pass one after another. Thus, the rigidity of the structure will gradually reduce. Using a pushover analysis it is possible to obtain a characteristic non-linear relationship, force - displacement curve, where the "representation" of seismic activity is done by the force of the base, and "representation" of the displacement is done by shifting the roof or the highest level. Target displacement is characteristic displacement of the structure, which serves as the estimate of the total-global displacement, coupled with a certain level of performance. At each step of the analysis, values of base shear force and the corresponding displacement gradually fill capacity curve. Performance Point is obtained using the capacity spectrum procedure. Special structural components controlled under permissible limits that depend on the global performance objectives. European anti-seismic design code, EC 8, applies exactly pushover analysis to evaluate the seismic performance of new and existing structures. In summary, the most critical indicators to assess the expected damage to the structure caused by the earthquake can assessed by pushover analysis. For example checks made specifically for maximum displacement between floors, points where plastic hinges are formed and the correlation between structure and possessing required ductility.

\section{Implementation of Pushover Analysis in Software SAP 2000 and Midas GEN}

Pushover analysis can be performed directly through the software that made structure modeling. However, the scheme of calculation and modeling assumptions accepted in non-elastic behavior of structural elements can affect the results of the analysis change with different software. Therefore, the basic principles of software used in pushover analysis should be well understood to interpret the results of this analysis. This paper presents the relevant steps used for performing Pushover Analysis with SAP 2000 software and MIDAS GEN software, as two advanced software in solving problems related to anti-seismic design. Generally, to perform pushover analysis with SAP software in 2000 and MIDAS GEN, the following steps should be followed: Main steps for performing Pushover Analysis with SAP 2000 software:

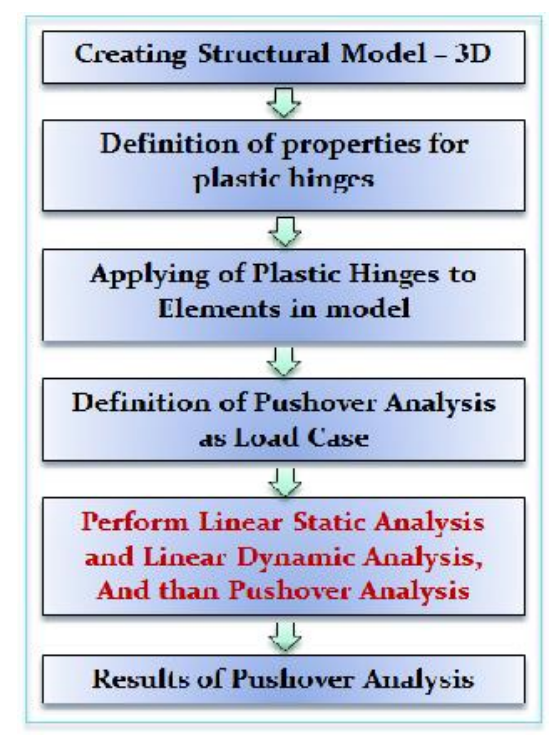




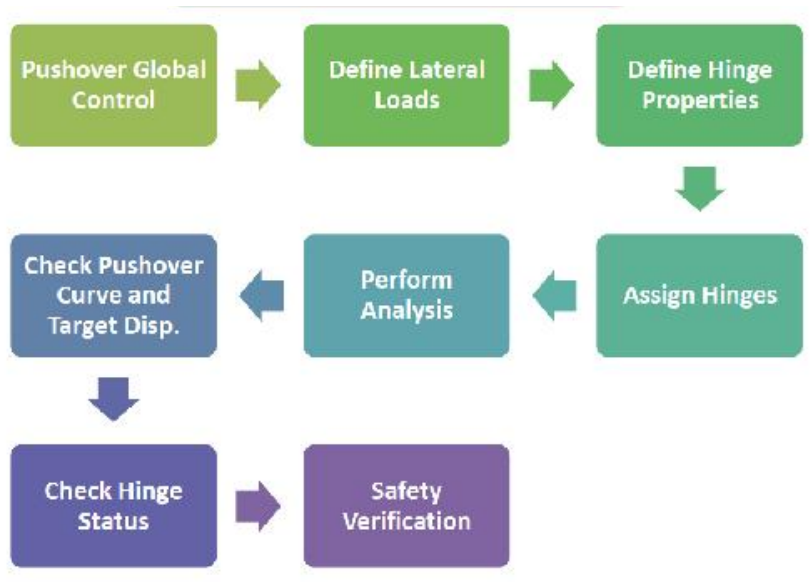

Fig 5. Main steps for performing Pushover Analysis with Midas GEN software

\section{Results of Pushover Analysis}

To illustrate the application of pushover analysis in estimating seismic demands of reinforced concrete structures, a spatial model of eight story reinforced concrete structure is analyzed. Structure is shown schematically in picture 4 . The dimensions of the columns are $60 / 80 \mathrm{~cm}$ and beams $45 / 60 \mathrm{~cm}$. Building have bays $3 \times 7 \mathrm{~m}$ in $\mathrm{x}$ direction and $8 \times 4 \mathrm{~m}$ in y direction. Concrete class is C $30 / 37$ and steel B500C. This variant is based on EC8 calculation, assuming the following parameters: Design ground acceleration $\mathrm{Ag}=0.22 \mathrm{~g}$, site class B, the behavior of the structure factor $\mathrm{q}=4$ and Importance coefficient $=1.0$. Calculations are performed using SAP 2000 software procedures (default type hinges, which are based on values from documents ATC-40 and FEMA-273) and Midas GEN software (where the key parameters of plastic hinges characteristics are defined by EC8 -3: 2004).
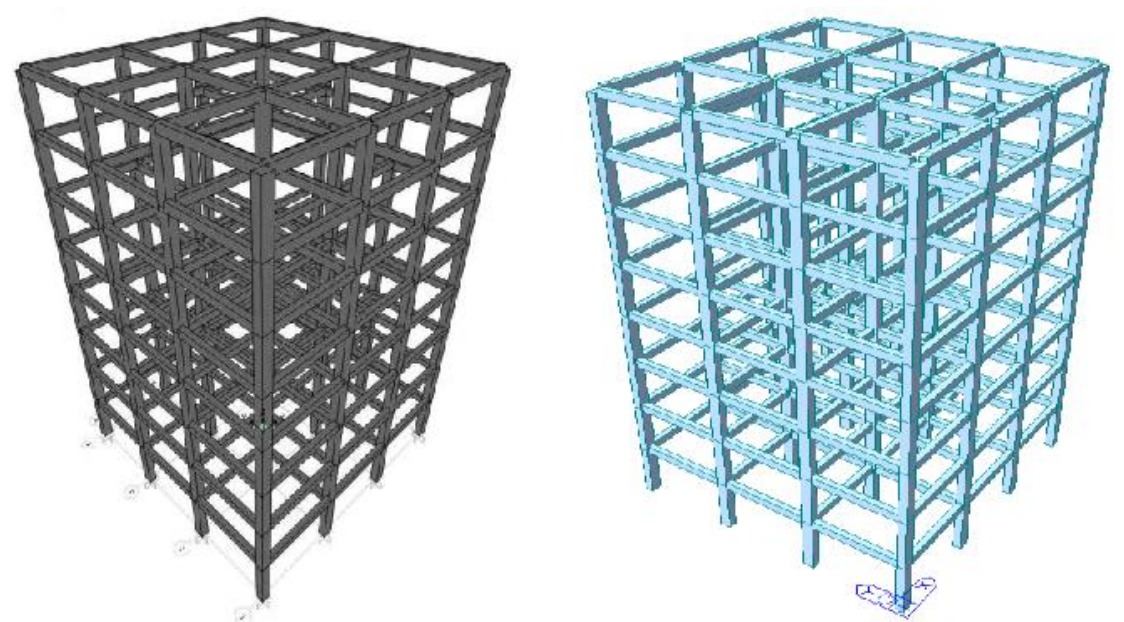

Fig. 5. Three dimensional Finite Element Models for eight story RC building 
From calculations performed for the case under examination it is showed that individual fundamental periods are $\mathrm{T} 1=1.17 \mathrm{~s}$. For the case of pushover analysis is presented deformed shapes of the structure and sequence of formation of plastic hinges, where certain colors determine the level of damage to the formed plastic hinges. The results of the data, Figure 5 shows that the collapse mechanism is formed in step 12, the corresponding displacement $60.49 \mathrm{~cm}$.
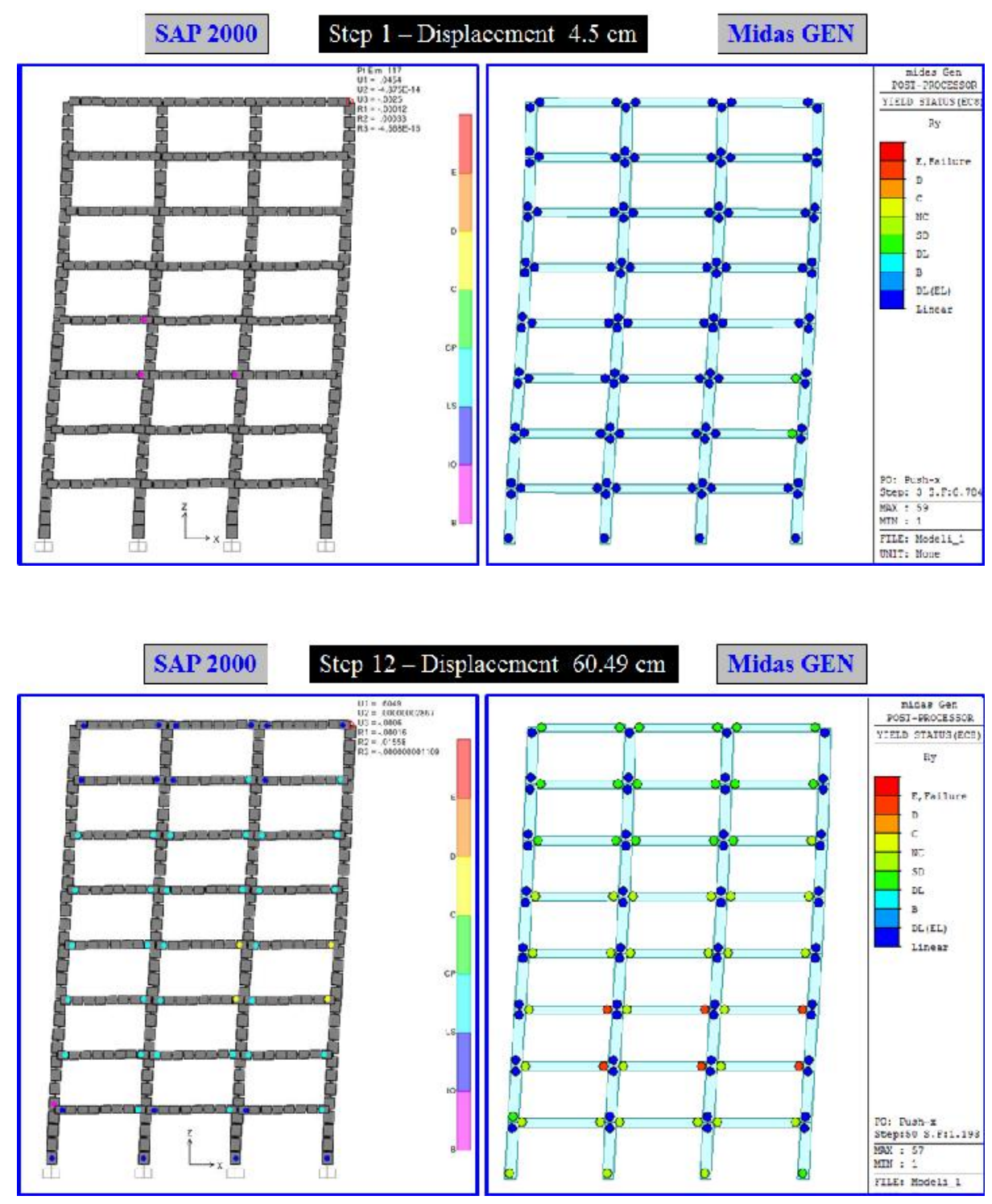

Fig. 6. Distribution of plastic hinges entire structure during Pushover Analysis

From every step of pushover analysis, base shear forces and corresponding displacement of the upper floor, is gradually filling capacity curve. From the results obtained in Fig. 6. The overloading coefficients $\alpha \mathrm{u} / \alpha 1$ are determined. Value of $\alpha 1$ represent value of base shear when first plastic hinge is formed. Value of $\alpha \mathrm{u}$ represent value of base shear when last plastic hinge is formed. 


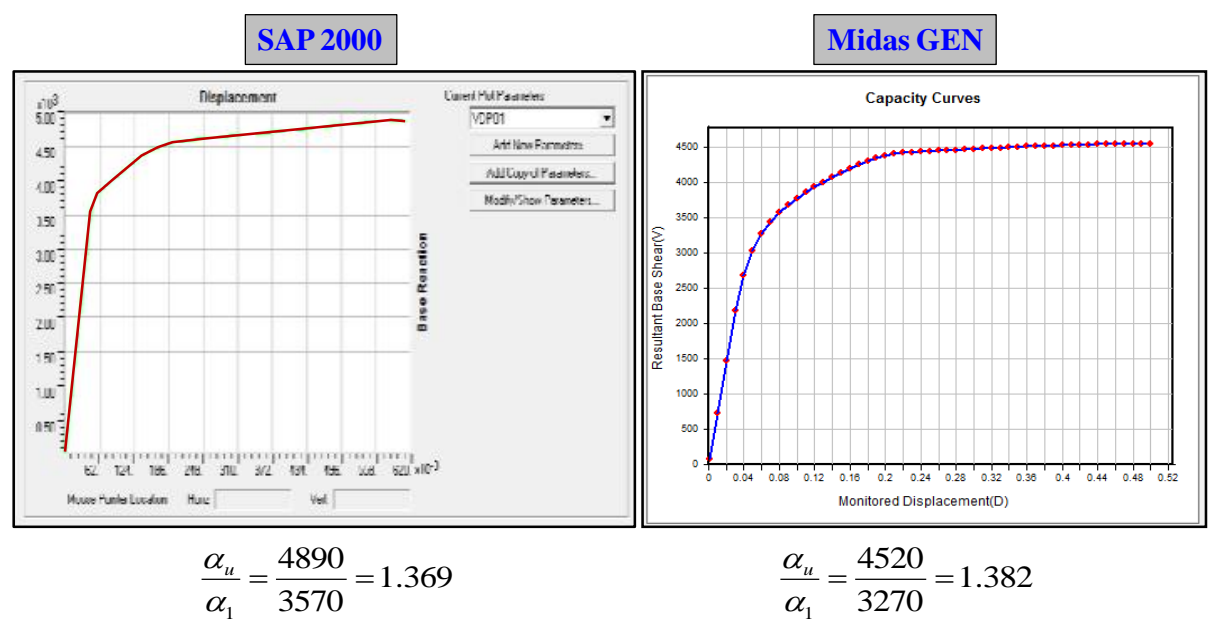

Fig. 7. Distribution of plastic hinges entire structure during Pushover Analysis

Results obtained for the relocation target with SAP 2000 are $13.6 \mathrm{~cm}$, whereas the MIDAS GEN value of this shift is $13.74 \mathrm{~cm}$. It is noted that the values obtained are approximately the same.

The performance point is obtained with intersection of the capacity curve and demand spectrum. The software enables conversion of capacity spectrum curve in acceleration - response format. Full Solution point performance is given in Fig. 8.

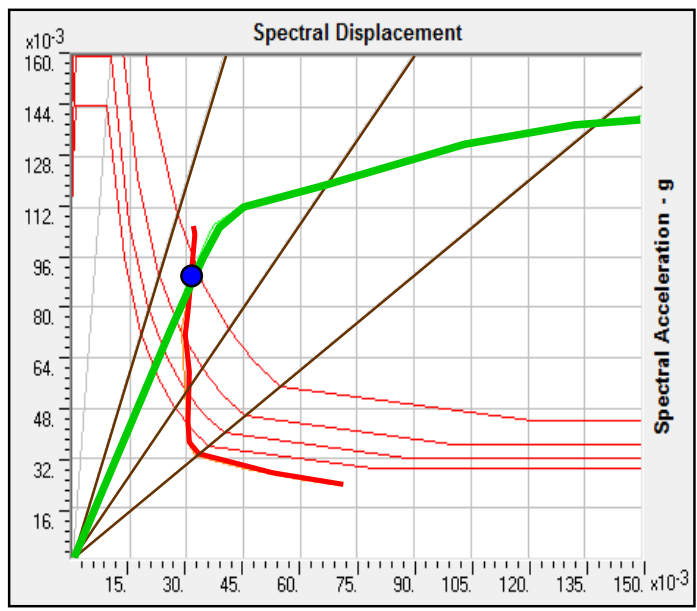

Fig. 8. Performance Point

\section{Conclusions}

Behavior of structures from earthquake requires special attention, looking for the correct engineering solution, but also economically acceptable. The problem is in setting the amount of expected damages, so the level of seismic risk to be accepted.

Inelastic rotation is one of the parameters usually considered in plastic hinges of beams and columns. The application of inelastic analysis, structural components is classified by mode of distribution of plasticity along the length of the element or concentration of elements in cross section. 
Despite the differences in the two software's SAP2000 and Midas GEN, and different codes give approximately the amount of capacity curve and sequences of formation plastic hinges, when nonlinear member behavior is modeled by concentrated plastic hinges.

By focusing on practical issues, pushover analysis requires calculation algorithms that reflect different stages of loading until reaching structural destruction. Effects related to vertical loads and P- $\Delta$ effect should be incorporated in the analysis.

\section{References}

1. CEN, (1994: Eurocode 8 - Design provisions for earthquake resistance of structures, Part 1 and 3 European prestandards ENV 1998, European Committee for Standardization, Brussels.

2. Chopra A.K. and Goel R.K.: A Modal Pushover Analysis Procedure to Estimating Seismic Demands for Buildings: Theory and Preliminary Evaluation, PERR Report 2001/03, Pacific Earthquake Engineering Research Center, University of California, Berkeley.

3. Computers and Structures Inc. (CSI), 2000: SAP2000 Three Dimensional Static and Dynamic Finite Element Analysis and Design of Structures, Berkeley, California.

4. Elnashai A.S., 2001: Advanced inelastic static (pushover) analysis for earthquake applications, Structural Engineering and Mechanics, Col. 12, No. 1, pp. 51-69.

5. Fajfar P. and Fischinger M., 1987: Nonlinear Seismic Analysis of R/C Buildings: Implications of a Case Study, European Earthquake Engineering, 31-43.

6. Federal Emergency Management Agency (FEMA), 1997: NEHRP Guidelines for the Seismic Rehabilitation of Buildings, FEMA-273.

7. Federal Emergency Management Agency (FEMA), 2000: Prestandard and Commentary for the Rehabilitation of Buildings, FEMA-356.

8. Krawinkler H. and Seneviratna G.D.P.K., 1998: Pros and Cons of a Pushover Analysis of Seismic Performance Evaluation, Engineering Structures, Vol.20, 452-464.

9. Midas GEN, 2011, Pushover Analysis Guide, Integrated system for Buildings and General Structures. 